\title{
ANALISIS DESKRIPTIF PROSES PEMBELAJARAN DARING DI SEKOLAH DASAR YAYASAN SERI AMAL MEDAN
}

\author{
Losten Tamba \\ FKIP Universitas Katolik Santo Thomas Medan \\ Email: losten.tamba@gmail.com
}

\begin{abstract}
ABSTRAK
Penelitian ini bertujuan menganalisis proses pembelajaran daring di sekolah dasar yang dikelola Yayasan Seri Amal Medan tahun pelajaran 2020/2021. Penelitian dilakukan secara deskriptif kuantitatif pada bulan Juni 2021 kepada siswa kelas 4 dan 5 SD Santo Antonius 1 dan 2 Medan, SD St. Paulus Sidikalang, SD Santo Pius Parsoburan, dan SD Santo Ignatius Medan yang berjumlah 621 siswa (responden). Data dikumpulkan dengan menggunakan angket skala likert yang mencakup perencanaan pembelajaran, pelaksanaan proses pembelajaran, penilaian pembelajaran, dan pengawasan pembelajaran daring. Data dianalisis dengan menghitung proporsi setiap pilihan instrumen. Dari penelitian ditemukan bahwa (a) pembelajaran didominasi dengan penggunaan whattsApp (WA), (b) sebagaian besar pembelajaran siswa didampingi oleh orangtua, (c) waktu melakukan pembelajaran dilakukan dengan tepat sesuai alokasi waktu, (d) guru menyampaikan materi dengan jelas namun perlu menggunakan model/strategi pembelajaran yang lebih tepat, dan (e) guru melakukan penilaian sesuai tujuan dengan bahasa yang mudah dipahami.

Kata Kunci : analisis deskriptif, pembelajaran daring
\end{abstract}

\begin{abstract}
This study aims to analyze the online learning process in elementary schools managed by the Medan Seri Amal Foundation for the 2020/2021 academic year. The research was conducted in a quantitative descriptive manner in June 2021 to 4th and 5th graders at SD Santo Antonius 1 and 2 Medan, SD St. Paulus Sidikalang, SD Santo Pius Parsoburan, and SD Santo Ignatius Medan, totaling 621 students (respondents). Data were collected using a Likert scale questionnaire that included lesson planning, implementation of the learning process, learning assessment, and online learning supervision. Data were analyzed by calculating the proportion of each choice of instrument. From the research it was found that (a) learning was dominated by the use of WhatsApp (WA), (b) most of the student learning was accompanied by parents, (c) the time for learning was carried out appropriately according to the time allocation, (d) the teacher delivered the material clearly but needed to using a more appropriate learning model/strategy, and (e) the teacher conducts an assessment according to the objectives in an easy-to-understand language.
\end{abstract}

Keywords: descriptive analysis, online learning

\section{PENDAHULUAN}

Pandemi covid-19 telah menjadi wabah penyakit yang menyebar ke seluruh

p-ISSN 2648-8600

e-ISSN 2745-410X

Volume 4 Nomor 2 Desember 2021 dunia termasuk Indonesia. Di Indonesia sendiri, Presiden Joko Widodo pada tanggal 2 Maret 2020, mengumumkan secara resmi bahwa telah terdapat warga 
negara Indonesia yang terjangkit virus corona. Dengan melihat perkembangan virus dari waktu ke waktu yang terus bertambah, maka pada tanggal 15 Maret 2020, Presiden Joko Widodo mengeluarkan himbauan pada masyarakat dan secara resmi kepada seluruh instansi untuk menghindari kontak dekat atau melakukan sosial distancing, menghindari kerumunan manusia dengan melaksanakan ibadah dan segala aktivitas dari rumah saja, dan melaksanakan aktivitas dari rumah atau yang biasa disebut Work From Home (WFH). Menindaklanjuti himbauan presiden, maka Kementrian Pendidikan dan Kebudayaan menuangkan surat edaran nomor 36603/A.A5/OT/2020 pada tanggal 15 Maret 2020 yang mengatur dengan resmi penerapan WFH.

Melalui penerapan WFH, maka terjadi penutupan sekolah secara fisik mulai dari pendidikan anak usia dini hingga perguruan tinggi, aktivitas belajar, dan pembelajaran yang biasa dilakukan di sekolah harus dilakukan di rumah (learning from home) secara daring dengan google classroom, video converence, telepon atau live chatt, zoom, whatsApp group, dan yang lainnya guna menekan pertumbuhan virus yang menyebar dengan sangat cepat.
Pembelajaran daring adalah solusi yang paling tepat untuk dilakukan, namun memberikan dampak yang signifikan bagi sekolah, guru, siswa, dan orang tua dikaitkan dengan kemampuan pengoperasiannya, penyediaan perangkat, pembuatan media, dan masalah-masalah yang lain.

Seperti sekolah-sekolah lain, unit sekolah yang dikelola Yayasan Seri Amal juga melakukan pembelajaran daring khususnya pada siswa sekolah dasar yang ada di Medan, Sidikalang, Parsoburan, dan Besitang. Efektivitas pembelajaran daring yang dilakukan di SD tersebut perlu dilakukan penelitian sehingga Kepala Sekolah dan Pengurus Yayasan Seri Amal dapat mengetahui pelaksanaannya secara faktual sehingga membuat tindak lanjut yang tepat untuk memperbaiki proses pembelajaran tersebut. Karena itu, permasalahan penelitian ini adalah bagaimana proses pembelajaran daring di sekolah dasar yang dikelola Yayasan Seri Amal pada masa pandemi covid-19?

\section{KERANGKA TEORETIK}

1. Konsep Analisis

Secara etimologis, kata analisis berasal dari bahasa Latin yaitu analusis 
yang artinya melepaskan. Kata

analusis berasal dari dua kata yaitu ana berarti kembali dan luein artinya melepas. Kamus Besar Bahasa Indonesia (KBBI), analisis adalah (1) penyelidikan terhadap suatu peristiwa (karangan, perbuatan, dan sebagainya) untuk mengetahui keadaan yang sebenarnya (sebab musabab, duduk perkara, atau hal-hal lainnya), (2) penguraian suatu pokok atas berbagai bagian itu sendiri serta hubungan antarbagian untuk memperoleh pengertian yang tepat dan pemahaman arti keseluruhan (2008: 58).

Menurut Sugiono (2015: 335), analisis adalah kegiatan untuk mencari pola, atau cara berpikir yang berkaitan dengan pengujian secara sistematis terhadap sesuatu untuk menentukan bagian, hubungan antarbagian, serta hubungannya dengan keseluruhan. Soedjadi (1995) mengatakan bahwa analisis adalah rangkaian kegiatan pemikiran logis, rasional, sistematis, dan obyektif, dengan menerapkan metodologi atau teknik ilmu pengetahuan untuk melakukan pengkajian, penelaahan, penguraian, pemerincian, dan pemecahan terhadap suatu obyek atau sasaran sebagai satu kebulatan komponen yang utuh ke dalam subkomponen-subkomponen yang lebih kecil sehingga dapat diperoleh kejelasan tentang fakta, data, dan informasi dari obyek tersebut. Berdasarkan pengertian dan pendapat tersebut dapat disimpulkan bahwa analisis adalah kegiatan mengurai, membedakan, memilah sesuatu untuk digolongkan, dan dikelompokan kembali menurut kriteria tertentu kemudian dicari hubungan dan ditafsirkan maknanya.

2. Proses Pembelajaran

Proses merupakan suatu kegiatan yang dilakukan untuk mencapai suatu keadaan atau tujuan yang telah ditentukan sebelumnya. Secara sederhana, proses dapat diartikan sebagai tahapan dalam melakukan sesuatu atau terjadinya sesuatu. Menurut Kamus Besar Bahasa Indonesia, proses merupakan suatu runtunan perubahan yang muncul dari suatu peristiwa dalam mengembangkan sesuatu (2008: 1106).

Pembelajaran adalah proses transaksional (saling memberikan timbal balik) di antara komponenkomponen sistem pembelajaran, yakni pendidik, peserta didik, bahan ajar, media, alat, prosedur dan proses belajar 
guna mencapai suatu perubahan yang komprehensif pada diri peserta didik. Perubahan yang komprehensif tersebut berarti perubahan yang mendalam dan esensial pada perilaku, sikap, pengetahuan, dan kemampuan pemaknaan pada peseta didik yang dapat berguna untuk menyelesaikan tugas/kewajiban-kewajiban dalam hidupnya, sehingga melalui sebuah kegiatan pembelajaran yang berkelanjutan, seluruh kebutuhan hidup peserta didik tersebut sebagai seorang insan manusia akan dapat terpenuhi (Fujiawati: 2016).

\section{Menurut Wina Sanjaya,} terdapat beberapa karakteristik penting dari istilah pembelajaran tersebut yaitu sebagai berikut:

1) Proses pembelajaran berarti membelajarkan siswa yang diukur dari sejauh mana siswa telah melakukan proses belajar.

2) Proses belajar dapat berlangsung dimana saja dengan memanfaatkan berbagai tempat untuk belajar sesuai dengan kebutuhan dan sifat materi ajar.

3) Proses pembelajaran berorientasi pada pencapaian tujuan pembelajaran yaitu mengubah tingkah laku siswa menjadi lebih baik (Ngalimun: 2017).

Proses pembelajaran berlangsung dengan melibatkan unsur guru, siswa, aktivitas guru dan siswa, interaksi antara guru dan siswa, bertujuan ke arah perubahan tingkah laku siswa dan proses maupun hasil telah direncanakan. Pembelajaran sendiri merupakan sebuah sistem yang dapat diartikan bahwa pembelajaran terdiri dari sejumlah komponen yang terorganisir dan saling berhubungan. Komponen di dalamnya antara lain berupa tujuan pembelajaran, materi pembelajaran, strategi dan metode pembelajaran, media pembelajaran, pengorganisasian kelas, evaluasi pembelajaran, dan tindak lanjut pembelajaran.

Proses pembelajaran pada satuan pendidikan seharusnya dapat diselenggarakan secara interaktif, inspiratif, menyenangkan, menantang, dan memotivasi peserta didik untuk berpartisipasi aktif serta memberikan ruang yang cukup bagi prakarsa, kreativitas, dan kemandirian sesuai bakat, minat, dan perkembangan fisik serta psikologis peserta didik. Proses pembelajaran ini telah ditetapkan 
sesuai dengan Peraturan Menteri

Pendidikan dan Kebudayaan Nomor 22

Tahun 2016 tentang Standar Proses

Pendidikan Dasar dan Menengah.

Peraturan ini menekankan pada prinsip pembelajaran di mana prinsip pembelajaran yang digunakan:

1) Lebih berpusat pada siswa di mana siswa dituntut untuk mencari tahu.

2) Guru menjadi belajar berbasis aneka sumber belajar dimana guru perlu mengembangkan pengetahuan yang dimiliki dengan memanfaatkan berbagai media yang tersedia.

3) Lebih berpusat pada pendekatan ilmiah dan/atau aplikatif.

4) Pembelajaran yang berbasis kompetensi dan terpadu.

5) Pembelajaran yang mengutamakan pembudayaan dan pemberdayaan peserta didik sebagai pembelajar sepanjang hayat.

6) Pembelajaran yang menerapkan nilai-nilai dengan memberi keteladanan, membangun kemauan, dan mengembangkan kreativitas peserta didik dalam proses pembelajaran.

7) Pembelajaran yang berlangsung di rumah, sekolah, dan masyarakat.
8) Pembelajaran yang menerapkan prinsip bahwa siapa saja bisa menjadi guru, siapa saja bisa mnejadi peserta didik, dan dimana saja adalah kelas.

9) Pemanfaatan teknologi informasi dan komunikasi untuk meningkatkan efisiensi dan efektifitas pembelajaran

10) Pengakuan atas perbedaan individu dan latar belakang budaya peserta didik.

Dalam standar proses pendidikan dasar dan menengah, proses pembelajaran ini mengacu kepada empat aspek yaitu:

1) Perencanaan Pembelajaran

Perencanaan pembelajaran dapat dirancang dalam bentuk silabus atau Rencana Pelaksanaan Pembelajaran (RPP) yang mengacu pada standar isi serta disesuaikan dengan pendekatan pembelajaran yang digunakan. Perencanaan pembelajaran dapat meliputi penyusunan rencana pelaksanaan pembelajaran dan penyiapan sumber belajar dan media, perangkat penilaian pembelajaran, dan skenario pembelajaran. 
2) Pelaksanaan Proses Pembelajaran

Pelaksanaan mengajar merupakan hasil proses belajar mengajar yang baik dan efektif yang muncul lewat interaksi yang baik antara pendidik dan peserta didik. Unsur yang ada dalam proses pembelajaran ini adalah materi ajar, metode, model, pendekatan, strategi, teknik, dan media pembelajaran. Pelaksanaan proses pembelajaran terdiri dari tiga tahap yaitu:

a) Kegiatan Pendahuluan

Kegiatan ini meliputi

menyiapkan peserta didik secara psikis dan fisik untuk mengikuti proses pembelajaran, memulai proses pembelajaran sesuai waktu yang ditentukan, (3) memberi motivasi belajar peserta didik secara kontekstual sesuai manfaat dan aplikasi materi ajar sesuai dengan kompetensi yang akan dicapai dalam kehidupan sehari-hari, dengan memberi contoh dan perbandingan lokal, nasional, dan internasional serta disesuaikan dengan karakteristik dan jenjang peserta didik, (4) mengajukan pertanyaan- pertanyaan yang mengaitkan pengetahuan sebelumnya dengan materi yang akan dipelajari, (5) menjelaskan tujuan pembelajaran atau kompetensi dasar yang akan dicapai, (6) menyampaikan cakupan materi dan penjelasan uraian kegiatan sesuai silabus dan RPP. Dalam kegiatan pendahuluan, guru juga dapat melakukan aktivitas-aktivitas lainnya sebagai berikut: (1) meminta seorang siswa untuk memimpin salam hormat kepada guru, (2) mendiskusikan kompetensi sebelumnya berkaitan dengan kompetensi yang akan dipelajari dan dikembangkan, dan (3) menyampaikan lingkup dan teknik penilaian yang akan digunakan.

b) Kegiatan Inti

Kegiatan inti menggunakan model pembelajaran, metode pembelajaran, media pembelajaran, dan sumber belajar yang ditelaah oleh guru yang disesuaikan dengan karakteristik peserta didik dan mata pelajaran. Pemilihan 
pendekatan tematik dan/atau tematik terpadu dan/atau saintifik dan/atau inkuiri dan penyingkapan (discovery) dan/atau pembelajaran yang menghasilkan karya berbasis pemecahan masalah (project based learning) disesuaikan dengan karakteristik kompetensi dan jenjang pendidikan.

c) Kegiatan Penutup

Dalam kegiatan penutup, guru bersaman peserta didik baik secara individual maupun kelompok harus melakukan refleksi untuk mengevaluasi seluruh rangkaian aktivitas pembelajaran dan hasil-hasil yang diperoleh untuk selanjutnya secara bersama menemukan manfaat langsung maupun tidak langsung dari hasil pembelajaran yang telah berlangsung. Selain itu, dalam bagian penutup dapat dilakukan (1) memberikan umpan balik terhadap proses dan hasil pembelajaran, melakukan kegiatan tindak lanjut dalam bentuk pemberian tugas baik secara individu maupun berkelompok, dan menginformasikan rencana kegiatan pembelajaran untuk pertemuan berikutnya.

3) Penilaian Proses Pembelajaran

Guru dapat melakukan penilaian terhadap proses pembelajaran. Aspek yang akan diukur dalam proses pembelajaran dapat berupa aspek penilaian sikap, pengetahuan, dan keterampilan. Setiap aspek dapat diukur menggunakan beberapa teknik penilaian dalam pembelajaran. Untuk mengukur aspek sikap siswa, guru dapat menggunakan teknik penilaian berupa observasi, penilaian diri, dan penilaian antarteman. Kemudian untuk mengukur pencapaian aspek pengetahuan siswa, guru dapat menggunakan teknik penilaian berupa tes tulis, tes lisan, dan penugasan. Lalu, untuk mengukur aspek keterampilan siswa, guru dapat menggunakan teknik penilaian berupa tes praktik, projek, penilaian portofolio, dan produk.

4) Pengawasan Pembelajaran

Pengawasan proses pembelajaran dapat berupa kegiatan pemantauan, supervise, evaluasi, serta tindak 
lanjut secara berkala dan berkelanjutan. Pihak yang bertugas mengawasi proses pembelajaran adalah kepala sekolah dan pengawas. Proses pengawasan, meliputi (a) pemantauan proses pembelajaran dilakukan pada tahap perencanaan, pelaksanaan, dan penilaian hasil pembelajaran, (b) supervisi proses pembelajaran, c) pelaporan hasil kegiatan pemantauan, supervise, dan evaluasi proses pembelajaran, dan (d) tindak lanjut hasil pengawasan dilakukan dalam bentuk penguatan, promosi, dan hukuman.

\section{Pembelajaran Daring}

Pembelajaran daring (online learning) digunakan untuk menyatakan makna yang sama. Daring merupakan istilah dalam bahasa Indonesia, sedangkan online merupakan istilah dalam bahasa Inggris. Berdasarkan Kamus Besar Bahasa Indonesia, daring memiliki arti dalam jaringan, terhubung melalui jejaring komputer, internet, dan sebagainya (Kemendikbud, 2020). Pembelajaran daring disebut juga pembelajaran jarak jauh atau pembelajaran dari rumah. Pembelajaran dari rumah yaitu proses interaksi peserta didik dengan pendidik dan sumber belajar secara tidak langsung menggunakan fasilitas atau media yang tersedia.

Menurut Isman, pembelajaran daring adalah sebuah proses pembelajaran dengan memakai koneksi internet ketika pembelajaran berlangsung (Isman, dalam Dwi dan Sri 2020:37). Pembelajaran daring diartikan proses belajar yang dilakukan tanpa adanya proses tatap muka dimana siswa dan instrukturnya (guru) berada di tempat yang berbeda sehingga diperlukan sistem telekomunikasi interaktif untuk menjadi media penghubung antar guru dan siswa serta memerlukan media pelengkapnya (Sobron \& Adi, dalam Dwi dan Sri, 2020:37).

Munir (dalam Indri Rahmawati, 2020:5) menyatakan pembelajaran daring merupakan sebagai usaha membuat sebuah transformasi proses pembelajaran yang ada di sekolah ke dalam bentuk digital yang dihubungkan oleh teknologi internet. Pembelajaran daring dilakukan dengan tidak bertatap muka langsung, tetapi menggunakan platform yang dapat membantu proses belajar mengajar yang dilakukan meskipun jarak jauh. Pembelajaran 
daring merupakan salah satu media atau metode pembelajaran paling efektif yang mampu menjangkau tempat yang sangat luas, dengan biaya yang relatif murah. Pembelajaran daring merupakan program pembelajaran dalam jaringan untuk menjangkau kelompok target yang masif dan luas (Bilfaqih dan Qomaruddin, 2015:1).

$$
\text { Pembelajaran }
$$

daring merupakan suatu program pembelajaran yang dilakukan dengan jarak jauh dan memanfaatkan teknologi informasi dalam proses pembelajarannya agar dapat menjangkau peserta lebih banyak dan menjangkau tempat yang sangat luas. Sistem pembelajaran daring merupakan program penyelenggaraan kelas dalam jaringan yang memanfaatkan teknologi informasi untuk dapat berkumpul bersama-sama dan berhubungan satu sama lain dalam proses pembelajaran meskipun jaraknya jauh.

\section{METODOLOGI PENELITIAN}

Penelitian ini bertujuan menganalisis proses pembelajaran daring di sekolah dasar yang dikelola Yayasan
Seri Amal Medan tahun pelajaran 2020/2021. Metode penelitian adalah deskriptif. Penelitian dilakukan pada bulan Juni 2021 dengan menggunakan angket skala likert yang mencakup perencanaan pembelajaran, pelaksanaan proses pembelajaran, penilaian pembelajaran, dan pengawasan pembelajaran daring kepada siswa SD kelas 4, 5, dan 6 di SD Santo Antonius 1 dan 2 Medan, SD St. Paulus Sidikalang, SD Santo Pius Parsoburan, dan SD Santo Ignatius Medan. Jumlah responden adalah 621 siswa. Data dianalisis secara deskriptif dengan menghitung proporsi setiap pilihan instrumen.

\section{HASIL PENELITIAN}

Dari angket yang diisi oleh responden secara virtual dengan google form ditemukan beberapa hal:

1. Guru melakukan pembelajaran dengan menggunakan WA sejumlah $72 \%$, zoom $21 \%$, dan $6 \%$ dengan google meet.

2. Ada 53\% responden yang menyatakan bahwa pembelajaran daring didampingi orangtua, $31 \%$ dilakukan secara mandiri, darn $15 \%$ oleh anggota keluarga.

3. Ada $63 \%$ responden yang menyatakan bahwa guru selalu 
mempersiapkan bahan dengan baik, $22 \%$ menjawab dengan sering, dan 13 menjawab kadang-kadang.

4. Guru selalu tepat waktu melaksanakan pembelajaran daring dijawab oleh $83 \%$ responden dan $12 \%$ dijawab dengan "sering".

5. Ada $67 \%$ responden menyatakan bahwa guru menyampaikan tujuan pembelajaran sebelum pembelajaran, pilihan sering dijawab oleh $17 \%$, dan ada $14 \%$ responden menjawab kadang-kadang.

6. Responden yang menyatakan guru selalu menyampaikan materi pembelajaran dengan jelas ada $67 \%$, pilihan sering dijawab 24\%, dan pilihan kadang-kadang dijawab 9\% .

7. Ada $13 \%$ responden yang menyatakan sangat setuju jika guru meningkatkan model/ strategi pembelajaran yang digunakan, $18 \%$ menyatakan ragu-ragu,dan $32 \%$ menyatakan tidak setuju.

8. Guru selalu melakukan pembelajaran kontekstual dijawab oleh $48 \%$ responden, 37\% dijawab sering, dan $15 \%$ dijawab kadang-kadang.

9. Sejumlah $66 \%$ responden mengatakan bahwa guru selalu menguasai atau mengkoordinasikan kelas dengan baik, 22\% menyatakan sering, dan 9\% menyatakan kadangkadang.

10. Guru selalu melaksanakan pembelajaran daring sesuai alokasi waktu dijawab oleh $71 \%$ responden dan $23 \%$ menjawab sering.

11. Ada $80 \%$ responden yang menyatakan bahwa guru selalu menjelaskan materi dengan bahasa yang baik, jelas, dan tepat, sedangkan yang menjawab sering ada $15 \%$.

12. Guru selalu melakukan penilaian yang sesuai dengan tujuan pembelajaran dijawab oleh $87 \%$ responden dan sisanya dijawab sering.

13. Guru selalu memberi waktu untuk bertanya dan menjawab pertanyaan siswa dijawab oleh $64 \%$ dan $20 \%$ menjawab dengan sering.

14. Sejumlah $72 \%$ responden menyatakan bahwa guru selalu mengoreksi tugas yang diberikan, 19\% menyatakan sering, dan 9\% menyatakan kadang-kadang.

15. Ada $28 \%$ responden menyatakan sangat setuju bahwa soal yang diujikan menggunakan bahasa yang mudah dipahami, $60 \%$ menyatakan setuju, dan $9 \%$ emyatakan ragu-ragu.

16. Ada $57 \%$ responden yang menyatakan bahwa guru selalu 
menyimpulkan hasil pembelajaran sebelum berakhir, $26 \%$ menyatakan sering, dan $14 \%$ menyatakan kadangkadang.

17. Guru selalu menginformasikan materi pembelajaran berikutnya sebelum menutup pembelajaran dijawab oleh $43 \%, 22 \%$ dijawab dengan sering, $27 \%$ dijawab dengan kadang-kadang, dan 9\% dijawab dengan tidak pernah.

\section{KESIMPULAN DAN SARAN}

1. Kesimpulan

a. Pembelajaran didominasi dengan penggunaan whattsapp (WA).

b. Sebagaian besar pembelajaran siswa didampingi oleh orangtua.

c. Waktu melakukan pembelajaran dilakukan dengan tepat sesuai alokasi waktu.

d. Guru menyampaikan materi dengan jelas namun perlu menggunakan model/strategi pembelajaran yang lebih tepat.

e. Guru melakukan penilaian sesuai tujuan dengan bahasa yang mudah dipahami.

f. Guru kurang dapat menutup pembelajaran dengan baik.

2. Saran
Affandi, Muhammad. 2013. Model Dan Metode Pembelajaran Di Sekolah. Semarang : UNISSULA Press

Arikunto Suharsimi. Dasar-dasar Evaluasi Pendidikan. Jakarta: Bumi Akasara, 2005. . Manajemen Penelitian. Jakarta: Rineka Cipta, 2009.

- Prosedur Penelitian. Jakarta: Rineka Cipta, 2010.

Fujiawati, Fuja Siti. 2016. Pemahaman Konsep Kurikulum dan Pembelajaran dengan Peta Konsep Bagi Mahasiswa Pendidikan Seni. Jurnal Pendidikan dan Kajian Seni, Vol.1, o.1, hlm.16-28

Haidir, dkk. 2014. Strategi Pembelajaran (Suatu Pendekatan Bagaimana 
Meningkatkan Kegiatan Belajar

Siswa Secara Transformatif).

Medan : IKAPI

Hamdani, dkk. 2018. Strategi Belajar Mengajar. Bandung : CV Pustaka Setia

Handarini, Oktafia Ika. 2020. Pembelajaran Daring Sebagai Upaya Study From Home (SFH). Jurnal Pendidikan Administrasi Perkantoran (JPAP),

Vol.8,No.3, hlm. 496-503

Helmiati. 2012. Model Pembelajaran. Yogyakarta : Aswaja Pressindo

Husannah, dkk. 2016. Belajar Dan Pembelajaran. Malang : UMMPress

Kementerian Pendidikan Dan Kebudayaan Nomor 36603/A.A5/OT/2020 tentang Pencegahan Penyebaran Corona Virus Disease (COVID-19) di Kementerian Pendidikan Dan Kebudayaan

Majid, Abdul. 2013. Perencanaan Pembelajaran. Bandung : PT Remaja Rosdakarya

Ngalimun, dkk. 2017. Strategi Dan Model Pembelajaran. Yogyakarta : Aswaja Pressindo
Peraturan Menteri Pendidikan dan Kebudayaan Nomor 22 tentang Standar Proses Pendidikan Dasar Dan Menengah.

Sanjaya, H, Wina. 2017. Strategi Pembelajaran Berorientasi Standar Proses Pembelajaran. Jakarta : Kencana Prenadamedia Group

Sugiyono. Metode Penelitian Kombinasi. Bandung: Alfabeta, 2011.

Sukmadinata, Nana Syaodih. Metode Penelitian Pendidikan. Bandung: Remaja Rosdakarya, 2015.

Suyono, dkk. 2016. Belajar Dan Pembelajaran : Teori Dan Konsep Dasar. Bandung : PT Remaja Rosdakarya 